\title{
Gillisia myxillae sp. nov., a novel member of the family Flavobacteriaceae, isolated from the marine sponge Myxilla incrustans
}

\author{
On On Lee, ${ }^{1}$ Stanley C. K. Lau, ${ }^{2}$ Mandy M. Y. Tsoi, ${ }^{1}$ Xiancui Li, ${ }^{1}$ \\ loulia Plakhotnikova, ${ }^{1}$ Sergey Dobretsov, ${ }^{1}$ Madeline C. S. Wu, ${ }^{1}$ \\ Po-Keung Wong ${ }^{3}$ and Pei-Yuan Qian ${ }^{1}$

\begin{abstract}
${ }^{1}$ Coastal Marine Laboratory/Department of Biology, The Hong Kong University of Science and Technology, Clear Water Bay, Kowloon, Hong Kong SAR, People's Republic of China

${ }^{2}$ Division of Environmental Science and Engineering, The National University of Singapore, Singapore

${ }^{3}$ Department of Biology, The Chinese University of Hong Kong, Shatin, NT, Hong Kong SAR, People's Republic of China
\end{abstract}

Correspondence

Pei-Yuan Qian

boqianpy@ust.hk
A yellow-pigmented, Gram-negative, rod-shaped, strictly aerobic bacterium (strain UST050418-085 ${ }^{\mathrm{T}}$ ) was isolated from the surface of a marine sponge, Myxilla incrustans, at Friday Harbor, WA, USA. The DNA G+C content of this strain was $34.6 \mathrm{~mol} \%$. The predominant fatty acids were $\mathrm{i} 15: 0, \mathrm{a} 15: 0, \mathrm{i} 15: 1, \mathrm{i} 16: 0, \mathrm{i} 17: 03-\mathrm{OH}, 17: 02-\mathrm{OH}$ and summed feature 3, comprising i15:0 2-OH and/or $16: 1 \omega 7 c$ (altogether representing 69.0\% of the total fatty acids). MK-6 was the only respiratory quinone detected. Phylogenetic analysis based on 16S rRNA gene sequences indicated that the closest relatives of UST050418-085 ${ }^{\top}$ were members of the genus Gillisia, with sequence similarities of $93 \cdot 2-96 \cdot 6 \%$. Strain UST050418-085 ${ }^{\top}$ differed from its closest relatives by 11 to 18 phenotypic traits. Molecular evidence and phenotypic characteristics suggest that strain UST050418-085 ${ }^{\top}$ represents a novel species within the genus Gillisia. The name Gillisia myxillae sp. nov. is proposed, with UST050418-085 $\left(=\mathrm{JCM} 13546^{\top}=\right.$ NRRL B-41416 $\left.{ }^{\top}\right)$ as the type strain.
The family Flavobacteriaceae contains many marine species that form a well-defined 'marine clade' in phylogenetic trees based on 16S rRNA gene sequences (Bowman, 2004). Gillisia is a recently established genus within this family (Van Trappen et al., 2004) and forms a phylogenetic cluster with the genera Mesonia, Salegentibacter and Psychroflexus (Nedashkovskaya et al., 2005). Currently, there are five species in the genus Gillisia, all of which were isolated from marine environments, including a microbial mat and sea-ice algae in Antarctica, as well as seawater in the Sea of Japan (Van Trappen et al., 2004; Bowman \& Nichols, 2005; Nedashkovskaya et al., 2005). In the present study, a novel member of the genus Gillisia, isolated from the surface of a marine sponge, is described.

During the characterization of bacteria isolated from the surface of the sponge Myxilla incrustans collected from Friday Harbor, San Juan Island, WA, USA, in April 2005,

The GenBank/EMBL/DDBJ accession number for the 16S rRNA gene sequence of strain UST050418-085 ${ }^{\top}$ is DQ202393.

A scanning electron micrograph of a cell of strain UST050418-085 ${ }^{\top}$ is available as supplementary material in IJSEM Online. strain UST050418-085 ${ }^{\mathrm{T}}$ was isolated on an agar medium consisting of 3 g yeast extract $l^{-1}, 5$ g peptone $1^{-1}$ and $0 \cdot 22$ $\mu \mathrm{m}$-filtered seawater (referred to as marine agar hereafter) after $48 \mathrm{~h}$ incubation at $24^{\circ} \mathrm{C}$. Unless otherwise specified, all characteristics described are those of cultures grown on marine agar under these conditions. UST050418-085 appeared as yellow, convex, circular colonies $(1-2 \mathrm{~mm}$ in diameter) with an entire edge and a smooth surface. No diffusible pigment was observed.

The nearly complete $16 \mathrm{~S}$ rRNA gene sequence of UST050418- $085^{\mathrm{T}}$ (1411 bp) was obtained bidirectionally with three replications as described by Lau et al. (2004). Phylogenetic analysis based on this nearly complete 16S rRNA gene sequence revealed that strain UST050418$085^{\mathrm{T}}$ was a member of the family Flavobacteriaceae. Its closest relatives were Gillisia mitskevichiae KMM $6034^{\mathrm{T}}$ (Nedashkovskaya et al., 2005), Gillisia limnaea LMG $21470^{\mathrm{T}}$ (Van Trappen et al., 2004) and Gillisia hiemivivida $\mathrm{IC} 154^{\mathrm{T}}$ (Bowman \& Nichols, 2005), with 96.6, 96.1 and 95.8\% 16S rRNA gene sequence similarity, respectively. A neighbourjoining (NJ) phylogenetic tree (Fig. 1) constructed using the ARB software package (Ludwig et al., 2004) placed strain 


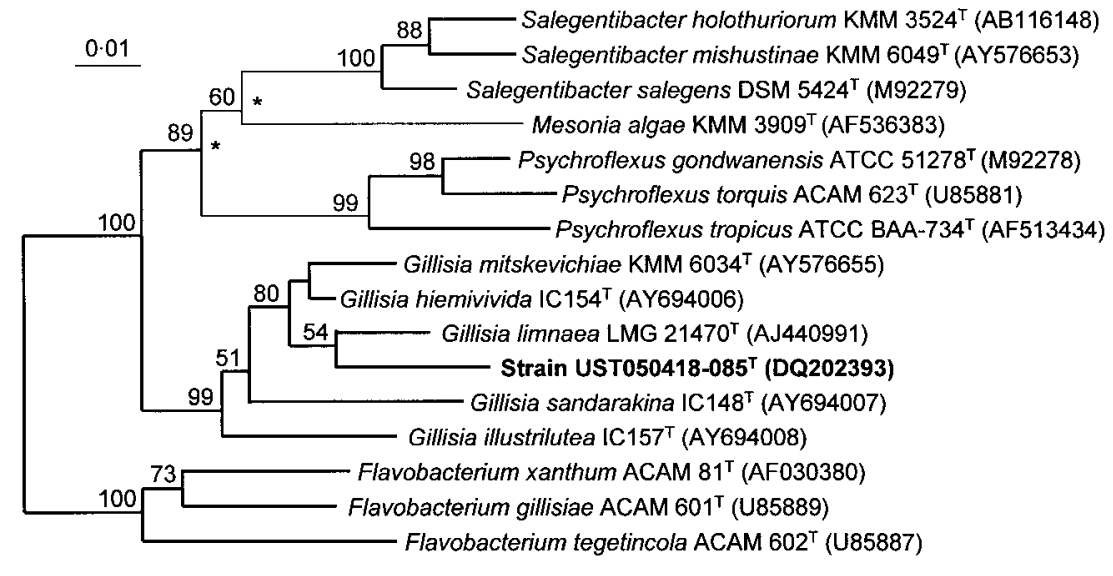

Fig. 1. Neighbour-joining tree showing the estimated phylogenetic relationships between UST050418-085 ${ }^{\top}$ and related species on the basis of $16 \mathrm{~S}$ rRNA gene sequences. Strains belonging to the genus Flavobacterium were chosen as the outgroups. Asterisks indicate nodes that are also found in the maximum-parsimony tree. Thick lines indicate branches found in both the maximum-likelihood and maximum-parsimony trees. Bootstrap values over 50\% (500 replicates) are shown at nodes. GenBank accession numbers are shown in parentheses. Bar, 1 substitution per $100 \mathrm{nt}$.
UST050418-085 ${ }^{\mathrm{T}}$ within the cluster comprising the five species of the genus Gillisia and showed that the most closely related strain was G. limnaea LMG $21470^{\mathrm{T}}$. Sequence similarity shows the similarity between two sequences based on a comparison of their nucleotide sequences in overlapping regions nucleotide-by-nucleotide. However, construction of $\mathrm{NJ}$ trees uses a phenetic method, is distance-based using a clustering algorithm and takes other factors (e.g. type of mismatch, mutation, gap, etc.) into account to generate a similarity matrix using ARB software (Ludwig et al., 2004). Therefore, the closest phylogenetic neighbour observed in the NJ tree is not necessarily the one with the highest sequence similarity because these comparisons are based on two different methods of calculating similarity. In fact, this phenomenon is common and found in other recent publications in the same genus or family (Van Trappen et al., 2004; Lau et al., 2005). Two other trees based on cladistic methods (i.e. character-based) were also constructed. One was made using the maximum-likelihood method, which selects the tree that is most likely to have produced the observed data; the other one was based on the maximumparsimony method, which selects the tree that requires fewer evolutionary changes (Ludwig et al., 2004). Both trees showed essentially the same topography for all species of the genus Gillisia (not shown). These results suggest that UST050418-085 ${ }^{\mathrm{T}}$ represents a novel species within the genus Gillisia.

The DNA G + C content of UST050418-085 ${ }^{\mathrm{T}}$, as determined by HPLC according to Mesbah et al. (1989), was $34 \cdot 6 \pm$ $0.1 \mathrm{~mol} \%$ (three replicates). This value is within the range of $\mathrm{G}+\mathrm{C}$ contents observed for members of the genus Gillisia (i.e. $32 \cdot 0-37 \cdot 8 \mathrm{~mol} \%)$. The cellular fatty acids of UST050418- $085^{\mathrm{T}}$ were determined using the Sherlock Microbial Identification System (MIDI) according to the manufacturer's protocol. The dominant fatty acids were i15:0, a15:0, i15:1, i16:0, i17:0 3-OH, 17:0 2-OH and summed feature 3, comprising i15:0 2-OH and/or $16: 1 \omega 7 c$, which altogether represent $69 \cdot 0 \%$ of the total fatty acids (Table 1). This fatty acid profile is similar to those of
G. limnaea LMG $21470^{\mathrm{T}}$ and G. mitskevichiae $\mathrm{KMM} 6034^{\mathrm{T}}$, confirming the close phylogenetic relationships observed for these bacteria (Fig. 1). MK-6 was the only respiratory quinone detected in UST050418-085 ${ }^{\mathrm{T}}$, as determined using an HPLC method according to Collins (1994). Menaquinones extracted from Cellulophaga lytica (Nakagawa \& Yamasato, 1993) and Pedobacter heparinus (Steyn et al., 1998) served as references for MK-6 and MK-7, respectively.

Anaerobic growth was examined using the Oxoid Anaerobic System. Growth at different temperatures $(4,12,20,28,36$, 44 and $\left.52^{\circ} \mathrm{C}\right)$ and $\mathrm{pH}$ values $(5,6,7,8,9$ and 10$)$ was monitored on marine agar for up to 10 days of incubation. The requirement for $\mathrm{NaCl}$ for growth was tested on a $1 \%$ agar medium containing $5 \mathrm{~g} \mathrm{MgCl}_{2}, 2 \mathrm{~g} \mathrm{MgSO}_{4}, 0.5 \mathrm{~g}$ $\mathrm{CaCl}_{2}, 1 \mathrm{~g} \mathrm{KCl}, 5 \mathrm{~g}$ peptone and different amounts of $\mathrm{NaCl}$, adjusted to pH 7.5 using KOH (Isnansetyo \& Kamei, 2003). Colony and cell morphology were examined using light $(\times 40$ magnification) and scanning electron microscopy (6700F; JEOL) according to Neu et al. (2001) (see Supplementary Fig. S1 available in IJSEM Online). The reaction to Gram stain was determined using light microscopy according to Smibert \& Krieg (1994). Gliding motility was observed under a phase-contrast light microscope (Olympia) after growth of the strain on quarter-strength marine 2216 medium (Oxoid) solidified with 1\% agar according to Bowman (2000). Susceptibility to antibiotics was tested according to Acar (1980). Flexirubin-type pigment production and carboxymethylcellulose hydrolysis were determined according to Bowman (2000). Casein hydrolysis was determined according to the procedures described by Norris et al. (1985); hydrolysis of Tweens 20, 40 and 80 and chitin was determined as described by Baumann \& Baumann (1981), whereas hydrolysis of agar, DNA and starch was tested according to Smibert \& Krieg (1994). Oxidase and catalase activities were determined as described by Smibert \& Krieg (1994). Other enzyme activities, substrate utilization patterns, nitrate reduction and production of $\mathrm{H}_{2} \mathrm{~S}$, indole and acetoin were tested using the commercial systems API 20E, API 20NE, API 50CH and 
Table 1. Cellular fatty acid profiles of UST050418-085 and other members of the genus Gillisia

Strains: 1, UST050418- $085^{\mathrm{T}} ; 2$, Gillisia limnaea LMG $21470^{\mathrm{T}} ; 3$, Gillisia mitskevichiae $\mathrm{KMM} 6034^{\mathrm{T}} ; 4$, Gillisia hiemivivida $\mathrm{IC} 154^{\mathrm{T}}$; 5, Gillisia sandarakina IC148 ${ }^{\mathrm{T}} ; 6$, Gillisia illustrilutea $\mathrm{IC}_{15} 7^{\mathrm{T}}$. Values given are mean percentages of the total fatty acid content. Data for reference strains were taken from Van Trappen et al. (2004), Bowman \& Nichols (2005) and Nedashkovskaya et al. (2005). br, Branching position has not been determined; i, isobranched fatty acids; a, anteiso-branched fatty acids; -, not detected. Summed feature 3 comprises i15:0 2-OH and/or $16: 1 \omega 7 c$.

\begin{tabular}{|lcccccc|}
\hline Fatty acid & $\mathbf{1}$ & $\mathbf{2}$ & $\mathbf{3}$ & $\mathbf{4}$ & $\mathbf{5}$ & $\mathbf{6}$ \\
\hline Straight-chain saturated & & & & & & \\
$15: 0$ & - & - & $4 \cdot 4$ & $4 \cdot 3$ & $4 \cdot 3$ & $4 \cdot 3$ \\
$16: 0$ & $1 \cdot 6$ & $0 \cdot 3$ & - & $1 \cdot 8$ & $0 \cdot 5$ & $1 \cdot 7$ \\
$15: 0$ 2-OH & $3 \cdot 8$ & $4 \cdot 0$ & $2 \cdot 4$ & - & - & - \\
15:0 3-OH & - & - & - & $1 \cdot 1$ & $0 \cdot 7$ & 0 \\
16:0 3-OH & $0 \cdot 5$ & $0 \cdot 1$ & $1 \cdot 2$ & - & - & - \\
$17: 0$ 2-OH & $7 \cdot 3$ & $13 \cdot 6$ & $3 \cdot 8$ & - & - & - \\
$17: 03-\mathrm{OH}$ & - & - & - & $1 \cdot 9$ & $5 \cdot 5$ & $6 \cdot 0$ \\
Straight-chain unsaturated & & & & & & \\
$15: 1 \omega 6 c$ & $0 \cdot 3$ & $1 \cdot 2$ & $1 \cdot 9$ & $2 \cdot 3$ & $1 \cdot 7$ & $1 \cdot 4$ \\
$17: 1 \omega 6 c$ & $2 \cdot 5$ & $1 \cdot 9$ & $4 \cdot 7$ & - & - & - \\
Branched saturated & & & & & & \\
i14:0 & - & $0 \cdot 2$ & $1 \cdot 2$ & $1 \cdot 3$ & $0 \cdot 6$ & $0 \cdot 6$ \\
i15:0 & $16 \cdot 6$ & $7 \cdot 2$ & $7 \cdot 5$ & $3 \cdot 5$ & $3 \cdot 2$ & $3 \cdot 2$ \\
a15:0 & $12 \cdot 5$ & $9 \cdot 7$ & $5 \cdot 1$ & $19 \cdot 5$ & $9 \cdot 1$ & $10 \cdot 2$ \\
i16:0 & $6 \cdot 2$ & $7 \cdot 4$ & $9 \cdot 3$ & $2 \cdot 7$ & $15 \cdot 8$ & $14 \cdot 4$ \\
a17:0 & $0 \cdot 3$ & $0 \cdot 2$ & - & - & - & - \\
i15:0 3-OH & $1 \cdot 9$ & $0 \cdot 7$ & $1 \cdot 1$ & $3 \cdot 8$ & $1 \cdot 5$ & $1 \cdot 4$ \\
a15:0 3-OH & - & - & - & $14 \cdot 6$ & $8 \cdot 6$ & $9 \cdot 9$ \\
i16:0 3-OH & $4 \cdot 9$ & $4 \cdot 3$ & $7 \cdot 2$ & $8 \cdot 9$ & $7 \cdot 0$ & $4 \cdot 9$ \\
i17:0 3-OH & $9 \cdot 4$ & $9 \cdot 8$ & $6 \cdot 7$ & $1 \cdot 4$ & $1 \cdot 7$ & $1 \cdot 4$ \\
a17:0 3-OH & - & - & - & $0 \cdot 3$ & $1 \cdot 2$ & $1 \cdot 6$ \\
Branched unsaturated & & & & & & \\
i15:1 & $8 \cdot 9$ & $9 \cdot 2$ & $11 \cdot 8$ & $3 \cdot 0$ & $13 \cdot 2$ & $14 \cdot 6$ \\
a15:1 & $2 \cdot 3$ & $2 \cdot 5$ & $2 \cdot 4$ & $13 \cdot 1$ & $12 \cdot 9$ & $17 \cdot 6$ \\
br16:1 & - & $3 \cdot 0$ & $6 \cdot 0$ & $4 \cdot 2$ & $6 \cdot 2$ & $3 \cdot 8$ \\
i17: 1 & $3 \cdot 6$ & $7 \cdot 3$ & $4 \cdot 0$ & $1 \cdot 8$ & $3 \cdot 4$ & $2 \cdot 2$ \\
a17:1 & $3 \cdot 5$ & $7 \cdot 7$ & $2 \cdot 1$ & $4 \cdot 7$ & $3 \cdot 0$ & $3 \cdot 3$ \\
Summed feature 3 & $7 \cdot 7$ & $8 \cdot 4$ & $11 \cdot 1$ & $4 \cdot 0$ & $4 \cdot 4$ & $2 \cdot 8$ \\
Unknown & $5 \cdot 4$ & $0 \cdot 7$ & $6 \cdot 7$ & - & - & - \\
& & & & & & \\
\hline
\end{tabular}

API ZYM (bioMérieux) and MicroLog 3 (Biolog). Cells for inoculating the API test systems were suspended in a sterile solution of seawater mixture at $22 \%$ salinity (MacDonell et al., 1982). Growth on glycerol, D-glucose, sucrose, D-mannitol, D-galactose, starch, D-sorbitol, D-arabinose and D-melibiose as sole carbon sources was also tested using a medium containing $0 \cdot 2 \mathrm{~g} \mathrm{NaNO}_{3}, 0 \cdot 2 \mathrm{~g} \mathrm{NH}_{4} \mathrm{Cl}, 0 \cdot 05 \mathrm{~g}$ yeast extract and $4 \%(\mathrm{w} / \mathrm{v})$ carbon source in 11 solution of seawater mixture at $35 \%$ salinity (Nedashkovskaya et al., 2003).
The morphological, physiological and biochemical characteristics of UST050418- $085^{\mathrm{T}}$ are listed in the species description. Strain UST050418- $085^{\mathrm{T}}$ differed from its three closest relatives by 11 to 18 traits, indicated in Table 2 . Molecular evidence, together with phenotypic characteristics presented in this study, suggest that UST050418-085 ${ }^{\mathrm{T}}$ constitutes a novel species within the genus Gillisia. The name Gillisia myxillae sp. nov. is proposed.

\section{Description of Gillisia myxillae sp. nov.}

Gillisia myxillae (my.xil'lae. N.L. fem. n. Myxilla systematic name of a genus of sponges; N.L. gen. fem. n. myxillae from Myxilla, referring to the isolation of the type strain from the sponge Myxilla incrustans).

Cells are Gram-negative, short rods $(1 \cdot 3-2 \cdot 0 \mu \mathrm{m}$ in length and $0.5 \mu \mathrm{m}$ in width), strictly aerobic, devoid of gliding and flagellar motility. Upon cultivation on marine agar, colonies are yellow in colour, $2-4 \mathrm{~mm}$ in diameter, circular and convex with a smooth surface and an entire edge. Does not produce flexirubin-type or diffusible pigments. MK-6 is the only respiratory quinone. Growth occurs between $\mathrm{pH} 5 \cdot 0$ and $10 \cdot 0(\mathrm{pH} \mathrm{7 \cdot 0-9.0} \mathrm{optimum)}$ and between 4.0 and $28 \cdot 0{ }^{\circ} \mathrm{C}\left(12 \cdot 0-20 \cdot 0{ }^{\circ} \mathrm{C}\right.$ optimum), but not at $36 \cdot 0{ }^{\circ} \mathrm{C}$ or higher. Requires $\mathrm{NaCl}(2 \cdot 0-10 \cdot 0 \% ; 4 \cdot 0-6 \cdot 0 \%$ optimum $)$ for growth. Predominant fatty acids are i15:0, a15:0, i15: 1 , i16:0, i17:0 3-OH, 17:0 2-OH and summed feature 3

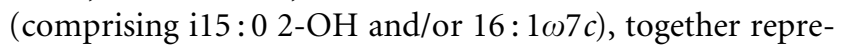
senting $69 \cdot 0 \%$ of the total. Susceptible to benzylpenicillin $(1 \cdot 0 \mu \mathrm{g})$, chloramphenicol $(1 \cdot 0 \mu \mathrm{g})$, ampicillin $(1 \cdot 0 \mu \mathrm{g})$ and tetracycline $(10.0 \mu \mathrm{g})$, but resistant to streptomycin and kanamycin (tested up to $100 \cdot 0 \mu \mathrm{g}$ ). Acetoin, indole and $\mathrm{H}_{2} \mathrm{~S}$ are not produced. Nitrate is not reduced. Citrate is not utilized. Casein, starch, and Tweens 20 and 40 are degraded, but agar, Tween 80 , chitin and carboxymethylcellulose are not. Positive for oxidase, DNase, alkaline phosphatase, esterase (C4), esterase lipase (C8), lipase (C14), leucine arylamidase, valine arylamidase, cystine arylamidase, acid phosphatase, naphthol-AS-BI-phosphohydrolase and tryptophan deaminase activities. Negative for gelatinase, urease, trypsin, $\alpha$-chymotrypsin, $\alpha$-galactosidase, $\beta$-galactosidase, $\beta$-glucuronidase, $\alpha$-glucosidase, $\beta$-glucosidase, $N$-acetyl- $\beta$ glucosaminidase, $\alpha$-mannosidase, $\alpha$-fucosidase, arginine dihydrolase, lysine decarboxylase and ornithine decarboxylase activities. Utilization of glycerol, D-glucose, sucrose, D-mannitol, D-galactose, starch, D-sorbitol, D-arabinose and D-melibiose as sole carbon sources is observed on agar medium supplemented with $4 \%(\mathrm{w} / \mathrm{v})$ carbon source and utilization of D-galacturonic acid, L-proline and putrescine is observed in the MicroLog 3 system. However, none of the carbon sources included in the API $20 \mathrm{NE}$ and $50 \mathrm{CH}$ systems are utilized. Acid is produced from L-arabinose, D-fructose, D-mannose, D-maltose, starch and glycogen in the API $50 \mathrm{CH}$ system, but no acid production is observed from the carbon sources in the API 20E system.

The type strain is UST050418-085 ${ }^{\mathrm{T}}\left(=\mathrm{JCM} 13546^{\mathrm{T}}=\mathrm{NRRL}\right.$ $\left.\mathrm{B}-41416^{\mathrm{T}}\right)$, isolated from the surface of the marine sponge 
Table 2. Phenotypic characteristics that differentiate UST050418-085 ${ }^{\top}$ from the three most closely related members of the genus Gillisia

Strains: 1, UST050418-085 ${ }^{\mathrm{T}}$; 2, G. limnaea LMG $21470^{\mathrm{T}}$; 3, G. mitskevichiae KMM $6034^{\mathrm{T}}$; 4, G. hiemivivida $\mathrm{IC} 154^{\mathrm{T}}$. Data for reference strains were taken from Van Trappen et al. (2004), Bowman \& Nichols (2005) and Nedashkovskaya et al. (2005). All strains are non-motile by gliding and incapable of hydrolysing agar, chitin and carboxymethylcellulose. All strains are positive for catalase and alkaline phosphatase activities. All strains are negative for reduction of nitrate, production of flexirubin-type pigments, $\mathrm{H}_{2} \mathrm{~S}$, indole and acetoin, utilization of citrate, D-melibiose and L-rhamnose and lysine decarboxylase and ornithine decarboxylase activities. Y, Yellow; O, orange; +, positive; $(+)$, weakly positive; -, negative; ND, not described.

\begin{tabular}{|c|c|c|c|c|}
\hline Characteristic & 1 & 2 & 3 & 4 \\
\hline DNA G + C content $(\mathrm{mol} \%)$ & $34 \cdot 6$ & $37 \cdot 8$ & $36 \cdot 4$ & $34 \cdot 0$ \\
\hline Pigment of cell biomass & $\mathrm{Y}$ & $\mathrm{Y}$ & $\mathrm{Y}$ & $\mathrm{O}$ \\
\hline $\mathrm{Na}^{+}$requirement for growth & + & - & + & + \\
\hline \multicolumn{5}{|l|}{ Tolerance of $\mathrm{NaCl}$ at: } \\
\hline $2 \cdot 0 \mathrm{M}$ & + & - & + & - \\
\hline $2 \cdot 5 \mathrm{M}$ & - & - & + & - \\
\hline Growth temperature $\left({ }^{\circ} \mathrm{C}\right)$ & $4 \cdot 0-28 \cdot 0$ & $5 \cdot 0-30 \cdot 0$ & $4 \cdot 0-31 \cdot 0$ & $-2 \cdot 0$ to $25 \cdot 0$ \\
\hline \multicolumn{5}{|l|}{ Susceptibility to: } \\
\hline Tetracycline & + & - & + & ND \\
\hline Streptomycin & - & - & + & ND \\
\hline \multicolumn{5}{|l|}{ Hydrolysis of: } \\
\hline Casein & + & - & + & - \\
\hline Gelatin & - & + & + & + \\
\hline Starch & + & - & - & + \\
\hline DNA & + & - & + & - \\
\hline Tween 20 & + & + & - & ND \\
\hline Tween 40 & + & - & + & ND \\
\hline Tween 80 & - & - & + & + \\
\hline \multicolumn{5}{|l|}{ Production of: } \\
\hline Lipase (C14) & + & - & ND & ND \\
\hline Urease & - & - & + & + \\
\hline Tryptophan deaminase & + & - & - & - \\
\hline Trypsin & - & + & ND & ND \\
\hline$\beta$-Glucuronidase & - & $(+)$ & - & - \\
\hline$\alpha$-Glucosidase & - & + & ND & + \\
\hline$\beta$-Glucosidase & - & + & ND & + \\
\hline \multicolumn{5}{|l|}{ Utilization of: } \\
\hline D-Glucose & - & + & + & + \\
\hline Sucrose & - & - & + & + \\
\hline L-Arabinose & - & - & - & + \\
\hline D-Mannose & - & - & - & + \\
\hline $\mathrm{N}$-Acetylglucosamine & - & - & + & + \\
\hline D-Maltose & - & - & ND & + \\
\hline Propionate & - & + & ND & + \\
\hline
\end{tabular}

Myxilla incrustans at Friday Harbor, San Juan Island, WA, USA. The DNA G $+C$ content of strain UST050418- $085^{\mathrm{T}}$ is $34 \cdot 6 \mathrm{~mol} \%$.

\section{Acknowledgements}

The authors thank Mr Ken Lau for respiratory quinone analysis and Professor Hans G. Trüper (University of Bonn, Germany) for generous help in Latin etymology. This work was supported by grants from the Research Grants Council (CA04/05.Sc01 and HKUST6240/04M) to P.Y.Q.

\section{References}

Acar, J. F. (1980). The disk susceptibility test. In Antibiotics in Laboratory and Medicine, pp. 24-54. Edited by V. Lorian. Baltimore: Williams \& Wilkins.

Baumann, P. \& Baumann, L. (1981). The marine gram-negative eubacteria: genera Photobacterium, Beneckea, Alteromonas, Pseudomonas and Alcaligenes. In The Prokaryotes, vol. 1, pp. 1302-1331. Edited by M. P. Starr, H. Stolp, H. G. Trüper, A. Balows \& H. Schlegel. Berlin: Springer.

Bowman, J. P. (2000). Description of Cellulophaga algicola sp. nov., isolated from the surfaces of Antarctic algae, and reclassification of 
Cytophaga uliginosa (ZoBell and Upham 1944) Reichenbach 1989 as Cellulophaga uliginosa comb. nov. Int J Syst Evol Microbiol 50, 1861-1868.

Bowman, J. P. (2004). Psychrophilic prokaryote structural-functional relationships, biogeography and evolution within marine sediment. Cell Mol Biol 50, 503-515.

Bowman, J. P. \& Nichols, D. S. (2005). Novel members of the family Flavobacteriaceae from Antarctic maritime habitats including Subsaximicrobium wynnwilliamsii gen. nov., sp. nov., Subsaximicrobium saxinquilinus sp. nov., Subsaxibacter broadyi gen. nov., sp. nov., Lacinutrix copepodicola gen. nov., sp. nov., and novel species of the genera Bizionia, Gelidibacter and Gillisia. Int J Syst Evol Microbiol 55, 1471-1486.

Collins, M. D. (1994). Isoprenoid quinones. In Chemical Methods in Prokaryotic Systematics, pp. 265-310. Edited by M. Goodfellow \& A. G. O'Donnell. Chichester: Wiley.

Isnansetyo, A. \& Kamei, Y. (2003). Pseudoalteromonas phenolica sp. nov., a novel marine bacterium that produces phenolic antimethicillin-resistant Staphylococcus aureus substances. Int J Syst Evol Microbiol 53, 583-588.

Lau, S. C. K., Tsoi, M. M. Y., Li, X., Plakhotnikova, I., Wu, M., Wong, P. K. \& Qian, P. Y. (2004). Loktanella hongkongensis sp. nov., a novel member of the $\alpha$-Proteobacteria originating from marine biofilms in Hong Kong waters. Int J Syst Evol Microbiol 54, 2281-2284.

Lau, S. C. K., Tsoi, M. M. Y., Li, X. \& 7 other authors (2005) Winogradskyella poriferorum sp. nov., a novel member of the family Flavobacteriaceae isolated from a sponge in the Bahamas. Int J Syst Evol Microbiol 55, 1589-1592.

Ludwig, W., Strunk, O., Westram, R. \& 29 other authors (2004). ARB: a software environment for sequence data. Nucleic Acids Res 32, 1363-1371.

MacDonell, M. T., Singleton, F. L. \& Hood, M. A. (1982). Diluent composition for use of API $20 \mathrm{E}$ in characterizing marine and estuarine bacteria. Appl Environ Microbiol 44, 423-427.
Mesbah, M., Premachandran, U. \& Whitman, W. B. (1989). Precise measurement of the $\mathrm{G}+\mathrm{C}$ content of deoxyribonucleic acid by highperformance liquid chromatography. Int J Syst Bacteriol 39, 159-167.

Nakagawa, Y. \& Yamasato, K. (1993). Phylogenetic diversity of the genus Cytophaga revealed by $16 \mathrm{~S}$ rRNA sequencing and menaquinone analysis. J Gen Microbiol 139, 1155-1161.

Nedashkovskaya, O. I., Kim, S. B., Hans, S. K. \& 7 other authors (2003). Mesonia algae gen. nov., sp. nov., a novel marine bacterium of the family Flavobacteriaceae isolated from the green alga Acrosiphonia sonderi (Kütz) Kornm. Int J Syst Evol Microbiol 53, 1967-1971.

Nedashkovskaya, O. I., Kim, S. B., Lee, K. H., Mikhailov, V. V. \& Bae, K. S. (2005). Gillisia mitskevichiae sp. nov., a novel bacterium of the family Flavobacteriaceae, isolated from sea water. Int J Syst Evol Microbiol 55, 321-323.

Neu, B., Voigt, A., Mitlohner, R. \& 7 other authors (2001). Biological cells as templates for hollow microcapsules. J Microencapsul 18, 385-395.

Norris, J. R., Ribbons, D. W. \& Varma, A. K. (editors) (1985). Methods in Microbiology, vol. 18. London: Academic Press.

Smibert, R. M. \& Krieg, N. R. (1994). Phenotypic characteristics. In Methods for General and Molecular Biology, pp. 607-654. Edited by P. Gerhardt, R. G. E. Murray, W. A. Wood \& N. R. Krieg. Washington, DC: American Society for Microbiology.

Steyn, P. L., Segers, P., Vancanneyt, M., Sandra, P., Kersters, K. \& Joubert, J. J. (1998). Classification of heparinolytic bacteria into a new genus, Pedobacter, comprising four species: Pedobacter heparinus comb. nov., Pedobacter piscium comb. nov., Pedobacter africanus sp. nov. and Pedobacter saltans sp. nov. Proposal of the family Sphingobacteriaceae. Int J Syst Bacteriol 48, 165-177.

Van Trappen, S., Vandecandelaere, I., Mergaert, J. \& Swings, J. (2004). Gillisia limnaea gen. nov., sp. nov., a new member of the family Flavobacteriaceae isolated from a microbial mat in Lake Fryxell, Antarctica. Int J Syst Evol Microbiol 54, 445-448. 